JKEP

Vol 6, No 2 (2021)

ISSN: 2338-9095 (Print)

ISSN: 2338-9109 (online)

\title{
Hubungan Stres Akademik Dan Kualitas Tidur Terhadap Sindrom Pramenstruasi Selama Pembelajaran Daring Di Masa Pandemi COVID-19
}

\author{
Arlia Fika Damayanti, Dora Samaria \\ Universitas Pembangunan Nasional Veteran Jakarta, Jakarta, Indonesia \\ email:dmynarlia@gmail.com
}

Artikel history
Dikirim, Sept 09th, 2020
Ditinjau, Oct 31th, 2021
Diterima, Nop 19th, 2021

\begin{abstract}
Premenstrual syndrome is the most common disorder experienced by women of childbearing age. There are various factors that can worsen the degree of premenstrual syndrome, including stress levels, sleep quality, nutritional status, smoking and alcohol. Various limitations during the distance learning process in the period of Covid-19 pandemic increased the academic stress and bad sleep quality of the students. This study aims to determine the relationship of academic stress and sleep quality to the degree of premenstrual syndrome in the Undergraduate Nursing students of Universitas Pembangunan Nasional Veteran Jakarta during the distance learning process in the period of the Covid-19 pandemic. This study used Cross sectional research design with a sample number of 160 respondents through Stratified Random Sampling method. Data collection is done through google form's questionnaire using Student-Life Stress Inventory (SLSI), Pittsburgh Sleep Quality Index (PSQI) and The Shortened Premenstrual Assessment Form (SPAF) that have undergone the validity and reliability test. The result showed that there was a significant relationship between academic stress (p-value 0.000) and sleep quality ( $p$ value 0.000) to the degree of premenstrual syndrome. This study recommends that students be able to manage and control academic stress conditions and sleep quality well to reduce the risk of premenstrual syndrome.
\end{abstract}

Keywords:Covid-19; sleep quality; distance learning; premenstrual syndrome; academic stress

\begin{abstract}
ABSTRAK
Sindrom pramenstruasi adalah gangguan menstruasi yang paling banyak dirasakan oleh wanita usia subur. Terdapat berbagai faktor yang dapat memperburuk derajat sindrom pramenstruasi, diantaranya adalah tingkat stres, kualitas tidur, status gizi, merokok dan alkohol. Berbagai keterbatasan selama proses pembelajaran jarak jauh di masa pandemi Covid-19 meningkatkan kondisi stres akademik dan kualitas tidur buruk pada mahasiswi. Penelitian ini bertujuan untuk mengetahui hubungan stres akademik dan kualitas tidur terhadap derajat sindrom pramenstruasi pada mahasiswi S1 Keperawatan Universitas Pembangunan Nasional Veteran Jakarta selama pembelajaran jarak jauh di masa pandemi Covid-19. Penelitian ini menggunakan desain
\end{abstract}


penelitian Crossectional dengan jumlah sampel 160 responden melalui metode Stratified Random Sampling. Pengumpulan data dilakukan melalui google form dengan menggunakan kuesioner Student-Life Stres Inventory (SLSI), Pittsburgh Sleep Quality Index (PSQI) dan The Shortened Premenstrual Assessment Form (SPAF) yang sudah dilakukan uji validitas dan reliabilitas. Hasil penelitian menunjukkan bahwa terdapat hubungan yang signifikan antara stres akademik ( $p$-value 0.000) dan kualitas tidur ( $p$-value 0.000) terhadap derajat sindrom pramenstruasi. Penelitian ini merekomendasikan kepada mahasiswa untuk dapat mengelola dan mengontrol kondisi stres akademik dan kualitas tidur dengan baik agar dapat menekan risiko sindrom pramenstruasi.

Kata kunci: Covid-19; kualitas tidur; pembelajaran jarak jauh; sindrom premenstruasi; stres akademik

\section{PENDAHULUAN}

Sindrom pramenstruasi (PMS) adalah berbagai gejala yang terjadi pada wanita dalam waktu 7-14 hari sebelum periode menstruasi (Afrilia \& Musa, 2020; Perry, Hockenberry, Alden, Kathryn Rhodes Lowdermilk, Cashion, \& Wilson, 2017, p. 65). Sindrom pramenstruasi dapat menimbulkan rasa tidak nyaman (Hashim dkk., 2019). Sindrom pramenstruasi dapat berupa gejala fisik, gejala psikologis dan perubahan tingkah laku (Abdi, Ozgoli, \& Rahnemaie, 2019). Gejala-gejala fisik yang sering dirasakan wanita yaitu pembengkakan atau nyeri perut, nyeri payudara, sakit kepala, nyeri sendi, nyeri otot dan nyeri punggung (Rodiani \& Rusfiana, 2016; Afrilia, \& Musa, 2020). Beberapa gejala psikologi dan perubahan tingkah yang paling sering dirasakan wanita yaitu mudah marah, perasaan tidak mampu mengatasi masalah, kelelahan, konsentrasi berkurang dan penambahan berat badan (Afrilia \& Musa, 2020; Susanti, Ilmiasih, \& Arvianti, 2017). Sebanyak 80\%-95\% wanita pada usia produktif dapat mengalami gejala-gejala tersebut (Machfudhoh, Sari, \& Novina, 2020).

Angka kejadian sindrom pramenstruasi di dunia cukup tinggi, yaitu mencapai $47.8 \%$, dengan prevalensi tertinggi adalah negara Iran sebesar 98\% dan prevalensi terendah terdapat di negara Swiss sebesar 10\% (Direkvand-Moghadam, Sayehmiri, Delpisheh, \& Satar, 2014). Prevalensi sindrom pramenstruasi di benua Asia lebih tinggi daripada benua lainnya (DirekvandMoghadam et al., 2014). Di Indonesia sebanyak 30\%-80\% wanita melaporkan sindrom pramenstruasi (Machfudhoh, Sari, \& Novina, 2020). Berdasarkan penelitian Christie et al., (2019) dilakukan di Jakarta, menunjukkan sebanyak 58,7\% responden mengalami sindrom pramenstruasi ringan dan $\quad 37.3 \%$ mengalami sindrom 
pramenstruasi sedang hingga berat (Christie, Citraningtyas, Ingkiriwang, \& Soesanto, 2019). Lalu hasil penelitian yang dilakukan pada 130 mahasiswi Universitas Indonesia menyatakan sekitar $36.9 \%$ mahasiswi mengalami sindrom pramenstruasi dengan derajat sedang hingga berat (Ilmi \& Utari, 2018). Derajat sindrom pramenstruasi dapat dipengaruhi oleh adanya ketidakseimbangan hormon yang dapat diakibatkan oleh pola hidup yang tidak sehat (Dhawan \& Hernole, 2020; Mariana, 2018).

Hingga saat ini, penyebab pasti terjadinya PMS masih belum diketahui dengan jelas (Royal College of Obstetricians and Gynaecologists, 2017). Beberapa penelitian menyatakan PMS dapat terjadi karena perubahan hormon sebelum menstruasi, yaitu adanya ketidakseimbangan antara hormon estrogen dan progesteron (Jarvis \& Hargreaves, 2015; Royal College of Obstetricians and Gynaecologists, 2017). Selain itu, terdapat beberapa faktor risiko yang dapat meningkatkan kejadian sindrom pramenstruasi antara lain tingkat stres, kualitas tidur, status gizi, merokok dan alkohol (Ilmi \& Utari, 2018). Namun, terdapat beberapa penelitian yang menyatakan bahwa stres akademik dan kualitas tidur tidak memengaruhi kejadian sindrom pramenstruasi (Ritung \& Olivia, 2018).
Berbagai perubahan yang terjadi pada mahasiswa selama proses pembelajaran jarak jauh dan pandemi Covid-19 tentunya berdampak pada psikologis mahasiswa. Sebagian besar mahasiswa yang melaksanakan proses pembelajaran jarak jauh mengalami stres akademik dan penurunan kualitas tidur (Hasanah, Ludiana, Immawati, \& PH, 2020; Jannah \& Santoso, 2021; Kusnayat, Sumarni, Mansyur, \& Zaqiah, 2020).

Studi pendahuluan yang dilakukan peneliti kepada 25 mahasiswi menunjukkan bahwa $100 \%$ responden tersebut mengalami stres akademik dengan indikator mahasiswi mengalami keadaan frustasi, konflik, tekanan perubahan ataupun pemaksaan diri akibat beban akademik. Berbagai kondisi tersebut dapat menimbulkan beberapa reaksi berupa gangguan pencernaan, keluar keringat berlebih, mual muntah dan kualitas tidur yang memburuk. Faktor yang melatarbelakangi kejadian stres akademik dan penurunan kualitas tidur tersebut antara lain beban tugas pembelajaran, kurang paham akan materi yang disampaikan, deadline pengumpulan tugas yang cepat, waktu perkuliahan yang padat, kondisi rumah yang kurang kondusif, ketidakefektifan dalam berkomunikasi dengan teman dan lain sebagainya (Hasanah et al., 2020; Kusnayat et al., 2020). Tingkat stres akademik mahasiswa 
keperawatan lebih tinggi dibandingkan jurusan lainnya (Rosyidah, Efendi, Arfah, Jasman, \& Pratami, 2020). Penelitian melaporkan prevalensi stres akademik mahasiswa Sarjana Keperawatan Universitas Pembangunan Nasional Veteran Jakarta selama proses pembelajaran jarak jauh bahwa beberapa mahasiswa mengalami stres sedang (34.3\%), sebagian mengalami stres berat (25.7\%), dan stres ringan sebanyak (14.3\%) (Rosaline \& Anggraeni, 2020). Mahasiswi yang mengalami stres akademik lebih tinggi daripada mahasiswa laki-laki (Dhull \& Kumari, 2015; Hafifah, Widiani, \& Rahayu, 2017). Tugas pembelajaran yang diberikan selama proses pembelajaran jarak jauh lebih banyak daripada pembelajaran di kampus (Kusnayat et al., 2020). Beban pembelajaran yang berlebih dan deadline pengumpulan tugas yang singkat dapat mengakibatkan kondisi stres pada mahasiswa (Hasanah et al., 2020).

Berdasarkan hasil studi pendahuluan juga didapatkan hasil sebanyak 100\% mahasiswi juga mengalami kualitas tidur yang buruk yang ditandai dengan durasi tidur $<7$ jam, latensi tidur $>30$ menit dan keadaan sering terbangun pada saat tidur selama pembelajaran jarak jauh (Sulana, Sekeon, \& Mantjoro, 2020). Banyaknya beban tugas pembelajaran dengan tuntutan waktu pengumpulan tugas yang tergolong cepat juga menjadi salah satu faktor penyebab memburuknya kualitas tidur mahasiswa. Mahasiswa mengalami kesulitan tidur karena memikirkan tugas (Kusnayat et al., 2020). Walaupun mahasiswa lebih banyak menghabiskan waktu di tempat tidur, namun secara keseluruhan kualitas tidur mahasiswa memburuk selama proses pembelajaran jarak jauh di masa pandemi Covid-19 (Romero-Blanco et al., 2020). Di masa pandemi Covid-19 diketahui terjadi penurunan kualitas tidur pada mahasiswa dengan presentasi kualitas tidur yang memburuk selama pandemi sebesar 73,3\% (Marelli et al., 2020). Keputusan Lockdown yang ditetapkan oleh pemerintah selama pandemi COVID-19 lebih berdampak terhadap kualitas tidur para mahasiswa daripada pekerja dan wanita daripada lakilaki (Marelli et al., 2020). Kualitas tidur yang buruk pada wanita dapat memperparah derajat PMS (Nelson, 2017). Mahasiswa dengan kualitas tidur yang buruk berisiko 3.5 kali lebih besar untuk mengalami PMS daripada mahasiswi dengan kualitas tidur yang baik (Ilmi \& Utari, 2018).

Selain itu, berdasarkan hasil studi penahulian peneliti juga mendapatkan sebanyak $88 \%$ responden mengatakan bahwa dirinya sering mengalami gejala 
pramenstruasi seperti nyeri perut, nyeri payudara, perubahan mood dan gangguan emosional. Mahasiswi mengatakan bahwa sindrom pramenstruasi yang dirasakan pada saat pembelajaran daring lebih parah daripada saat pembelajaran luring. Hal tersebut menyebabkan, mahasiswi mengalami penurunan konsentrasi pada saat melakukan proses pembelajaran. Sindrom pramenstruasi dapat mengganggu produktivitas pendidikan, aktivitas seharihari dan dapat menyebabkan beberapa masalah kesehatan yang parah. Oleh karena itu, peneliti ingin mengetahui gambaran stres akademik dan kualitas tidur mahasiswi akibat proses pembelajaran jarak jauh di masa pandemi Covid-19 dan juga mengetahui korelasi antara dua variabel tersebut dengan derajat sindrom pramenstruasi yang dirasakan para mahasiswi selama masa pembelajaran jarak jauh di masa pandemi Covid-19.

\section{METODE}

Penelitian ini menggunakan design observational analytic dengan pendekatan crosssectional. Dalam penelitian ini terdapat dua variabel independen yaitu stres akademik dan kualitas tidur. Variabel dependen pada penelitian ini adalah derajat sindrom pramenstruasi. Proses pengumpulan data dilakukan sejak April Juni 2021 melalui google form dengan menggunakan tiga kuesioner. Kuesioner penelitian yang digunakan yaitu StudentLife Stres Inventory (SLSI), Pittsburgh Sleep Quality Index (PSQI) dan The Shortened Premenstrual Assessment Form (SPAF) yang sudah dilakukan uji validitas dan reliabilitas. Kuesioner Student-Life Stres Inventory (SLSI) adalah kuesioner yang akan mengukur kondisi stres akademik pada mahasiswi, terdiri dari 49 pertanyaan favorable dan 2 pertanyaan unfavorable. Seluruh pertanyaan pada kuesioner ini dinyatakan valid dengan nilai r hitung $0.301-0.810>\mathrm{r}$ tabel 0.279 dan reliabel dengan nilai croncbach alpha 0.963. Kuesioner Pittsburgh Sleep Quality Index (PSQI) adalah kuesioner yang akan mengukur kualitas tidur mahasiswi, terdiri dari 7 komponen penilaian kualitas tidur. Seluruh pertanyaan pada kuesioner ini dinyatakan valid dengan nilai $r$ hitung $0.327-0.868>\mathrm{r}$ tabel 0.279 dan reliabel dengan nilai croncbach alpha 0.801 . Kuesioner The Shortened Premenstrual Assessment Form (SPAF) adalah kuesioner yang akan mengukur derajat sindrom pramenstruasi pada mahasiswi, terdiri dari 10 gejala PMS. Seluruh pertanyaan pada kuesioner ini dinyatakan valid dengan nilai r hitung $0.394-0.793>\mathrm{r}$ tabel 0.279 dan reliabel dengan nilai croncbach alpha 0.843 . 
Penelitian ini dilakukan pada mahasiswi S1 Keperawatan, UPN Veteran Jakarta dengan total populasi 268 mahasiswi. Teknik sampling yang digunakan adalah Stratified Random Sampling. Langkah pertama yang peneliti lakukan dalam penelitian ini membuat daftar nama mahasiswi S1 Keperawatan, UPN Veteran Jakarta yang telah sesuai dengan kriteria inklusi dan kriteria eksklusi pada penelitian ini berdasarkan tingkat perkuliahan mahasiswi. Selanjutnya peneliti mengurukan data responden berdasarkan NIM pada setiap strata dan memberikan Nomor Responden pada setiap responden penelitian. Kemudian peneliti menghitung jumlah sampel yang dibutuhkan pada peneltian ini dengan menggunakan rumus Slovin. Total sampel pada penelitian ini adalah 160 responden. Peneliti memilih sampel dari setiap strata sesuai dengan jumlah yang sudah ditetapkan secara acak dengan membuat dan mencatat seluruh populasi di gulungan kertas berupa penomoran responden penelitian, kemudian setelah semuanya terkumpul diletakkan dikotak undian dan diambil secara acak hingga jumlah sampel yang diinginkan terpenuhi.

Analisa data univariat pada penelitian ini dilakukan untuk mengetahui gambaran usia responden, usia menarche, lama menstruasi, siklus menstruasi, riwayat keluarga dengan PMS, stres akademik, kualitas tidu dan Derajat Sindrom Pramenstruasi. Analisa data bivariat pada penelitian ini menggunakan Uji Pearson ChiSquare. Tujuan dari analisis uji pearson chisquare adalah untuk mengetahui hubungan dari stres akademic dan kualitas tidur terhadap derajat premenstrual syndrome pada mahasiswi selama proses pembelajaran jarak jauh (PJJ) dimasa pandemi Covid-19. Penelitian ini memiliki etika penelitian menghormati harkat dan martabat responden, menghormati privacy dan menjaga kerahasiaan data responden, adil dan tidak membeda-bedakan responden, serta tidak menimbulkan risiko negatif terhadap responden penelitian. Penelitian ini sudah mendapat Persetujuan Etik, yang dikeluarkan oleh Komisi Etik Penelitian Kesehatan, UPN Veteran Jakarta dengan Nomor: 207/V/2021/KEPK.

\section{HASIL DAN PEMBAHASAN}

Berdasarkan hasil pengolahan dan Analisa data yang telah peneliti lakukan, maka dapat dilaporkan hasil sebagai berikut:

\section{Analisa Univariat}

\section{Karakteristik Responden}

a. Usia, Usia Menarche, Lama Menstruasi, Siklus Menstruasi dan Riwayat Keluarga dengan PMS 
Table 1 Karakteristik Responden Mahasiswi Program Studi S1 Keperawatan di UPN Veteran Jakarta Tahun 2021 ( $\mathrm{n}=160$; April - Juni 2021)

\begin{tabular}{|c|c|c|}
\hline Variabel & Mean & Median \\
\hline Usia & 20.26 & 20.00 \\
\hline Variabel & $\begin{array}{l}\text { Frekuensi } \\
\text { (n) }\end{array}$ & $\begin{array}{c}\text { Presentase } \\
(\%)\end{array}$ \\
\hline \multicolumn{3}{|l|}{ Usia Menarche : } \\
\hline $\begin{array}{c}\text { Dini } \\
(<10 \text { Tahun }) \\
\end{array}$ & 5 & 3.1 \\
\hline $\begin{array}{c}\text { Normal } \\
(10-13 \text { Tahun })\end{array}$ & 105 & 65.6 \\
\hline $\begin{array}{c}\text { Terlambat } \\
\text { (>13 Tahun) }\end{array}$ & 50 & 31.3 \\
\hline Total & 160 & 100 \\
\hline \multicolumn{3}{|c|}{ Lama Menstruasi : } \\
\hline $\begin{array}{c}\text { Memendek } \\
(<4 \text { Hari })\end{array}$ & 7 & 4.4 \\
\hline $\begin{array}{l}\text { Normal } \\
\text { (4-8 Hari) }\end{array}$ & 144 & 90.0 \\
\hline $\begin{array}{l}\text { Memanjang } \\
(>8 \text { Hari) }\end{array}$ & 9 & 5.6 \\
\hline Total & 160 & 100 \\
\hline \multicolumn{3}{|c|}{ Siklus Menstruasi : } \\
\hline $\begin{array}{c}\text { Polimenorae } \\
(<21 \text { hari })\end{array}$ & 10 & 6.3 \\
\hline $\begin{array}{c}\text { Normal } \\
(21-35 \text { hari })\end{array}$ & 133 & 83.1 \\
\hline $\begin{array}{c}\text { Oligominorae } \\
(>35 \text { hari })\end{array}$ & 17 & 10.6 \\
\hline Total & 160 & 100 \\
\hline \multicolumn{3}{|c|}{ Riwayat Keluarga dengan PMS : } \\
\hline $\mathrm{Ya}$ & 36 & 22.5 \\
\hline Tidak & 124 & 77.5 \\
\hline Total & 160 & 100 \\
\hline
\end{tabular}

Usia rata-rata mahasiswi S1 Keperawatan, UPN Veteran Jakarta adalah 20.26 tahun dengan sebagian besar mahasiswi mengalami menstruasi pertama pada usia yang normal yaitu 10-13 tahun sebanyak 105 responden (65.6\%). Usia tidak menjadi salah satu faktor risiko dari kejadian sindrom pramenstruasi. Hal ini disebabkan mayoritas remaja merasakan sindrom pramenstruasi dengan gejala dan derajat yang serupa dengan yang dialami oleh wanita dewasa (Freeman, 2007). Pernyataan tersebut terlah terbukti secara statistik dengan hasil uji regresi logistik multivariat didapatkan nilai $p$-value $>0.05$ $(1.00>0.05)$, artinya tidak terdapat 
hubungan secara statistik antara usia dengan kejadian sindrom pramenstruasi (Mufida, 2017). Perbedaan usia menarche pada setiap wanita dapat dipengaruhi oleh beberapa faktor seperti faktor genetik, status sosial dan status gizi (Purwani Sari, 2019). Usia menarche memiliki hubungan yang signifikan terhadap kejadian PMS (Karajibani, Montazerifar, Nazare, \& Dashipour, 2019). Usia menarche dapat mempengaruhi kejadian PMS karena hormon gonadotropin (estrogen dan progesterone) pada wanita belum diproduksi ketika wanita belum mengalami siklus seksualnya (Guyton \& Hall, 2016). Semakin cepat usia menarche seorang wanita, maka akan meningkatkan derajat sindrom pramenstruasi yang dirasakannya (Christie et al., 2019). Mahasiswi yang mengalami usia menarche dini memiliki risiko mengalami PMS 0.5 kali lebih besar daripada mahasiswi yang usia menarche normal ataupun lambat (Fatimah, Prabandari, \& Emilia, 2016).

Periode lama menstruasi mahasiswi S1 Keperawatan, UPN Veteran Jakarta adalah normal yaitu 4-8 hari (90.0\%) dengan siklus menstruasi yang normal pula yaitu 21-35 hari (83.1\%). Lama menstruasi dapat dipengaruhi oleh faktor psikologis dan faktor fisiologis. Faktor psikologis yang dapat mempengaruhi lama menstruasi yaitu tingkat emosional yang labil dan kondisi stres. Sedangkan secara fisiologis lama menstruasi dipengaruhi oleh kontraksi otot uterus yang berlebih. Menstruasi yang berlangsung lama disebabkan oleh kontraksi otot uterus yang memanjang, sehingga akan meningkatkan produksi hormon prostaglandin yang diproduksi tubuh dan hal tersebut dapat mengakibatkan kejadian PMS (Mau, Kurniawan, \& Dewajanti, 2020). Wanita yang memiliki lama menstruasi $>5$ hari berisiko 1.9 kali lebih besar untuk mengalami PMS (Joshi, Patil, Kural, Noor, \& Pandit, 2015). Mayoritas mahasiswi memiliki siklus menstruasi yang normal karena pada rentang usia mahasiswi, telah terjadi kematangan organ reproduksi seksual (Novia \& Puspitasari, 2018). Penelitian ini sejalan dengan penelitian yang telah dilakukan, dimana dalam penelitian tersebut didapatkan hasil bahwa mayoritas responden mahasiswi memiliki siklus menstruasi yang normal (60.4\%) (Andriana, Aldriana, \& Andria, 2018). Penelitian lain menunjukkan bahwa sebesar 97 responden (61.4\%) memiliki siklus menstruasi normal, 16 responden $(10.1 \%)$ polimenorae dan 45 responden $(28.5 \%)$ oligomenorae (Simbolon, Sukohar, \& Ariwibowo, 2018). Terdapat berbagai faktor yang dapat mempengaruhi siklus 
menstruasi, antara lain faktor genetik, faktor psikologi, status gizi, kebiasaan merokok dan alkohol (Islamy \& Farida, 2019).

Sebagian besar mahasiswi S1 Keperawatan, UPN Veteran Jakarta tidak memiliki riwayat keluarga dengan PMS (77.5\%). Sedangkan sebanyak 36 responden (22.5\%) memiliki riwayat keluarga dengan PMS. Gangguan menstruasi dipengaruhi oleh faktor internal dan faktor eksternal seperti faktor hormon, kondisi stres dan pola menstruasi di keluarga (Jayakumari, Prabhu, Johnson, \& Kalaiselvi, 2016). Sebuah penelitian melaporkan bahwa terdapat korelasi antara riwayat keluarga dengan PMS dengan derajat sindrom pramenstruasi yang dibuktikan melalui hasil statistik dengan menggunakan uji ChiSquare (p-value 0.001). Pada penelitian tersebut dikatakan bahwa seorang anak perempuan yang memiliki Ibu atau saudara perempuan kandung dengan riwayat PMS akan berisiko lebih besar menderita sindrom pramenstruasi (Afrilia \& Musa, 2020). Wanita yang memiliki riwayat keluarga dengan PMS berisiko 3 kali lebih besar untuk mengalami PMS (Kushartanti, 2018).

\section{Variabel Independen}

\section{a. Stres Akademik}

Table 2 Distribusi Frekuensi Responden Berdasarkan Stres Akademik pada Mahasiswi Program Studi S1 Keperawatan di UPN Veteran Jakarta Tahun 2021 (n=160; April - Juni 2021)

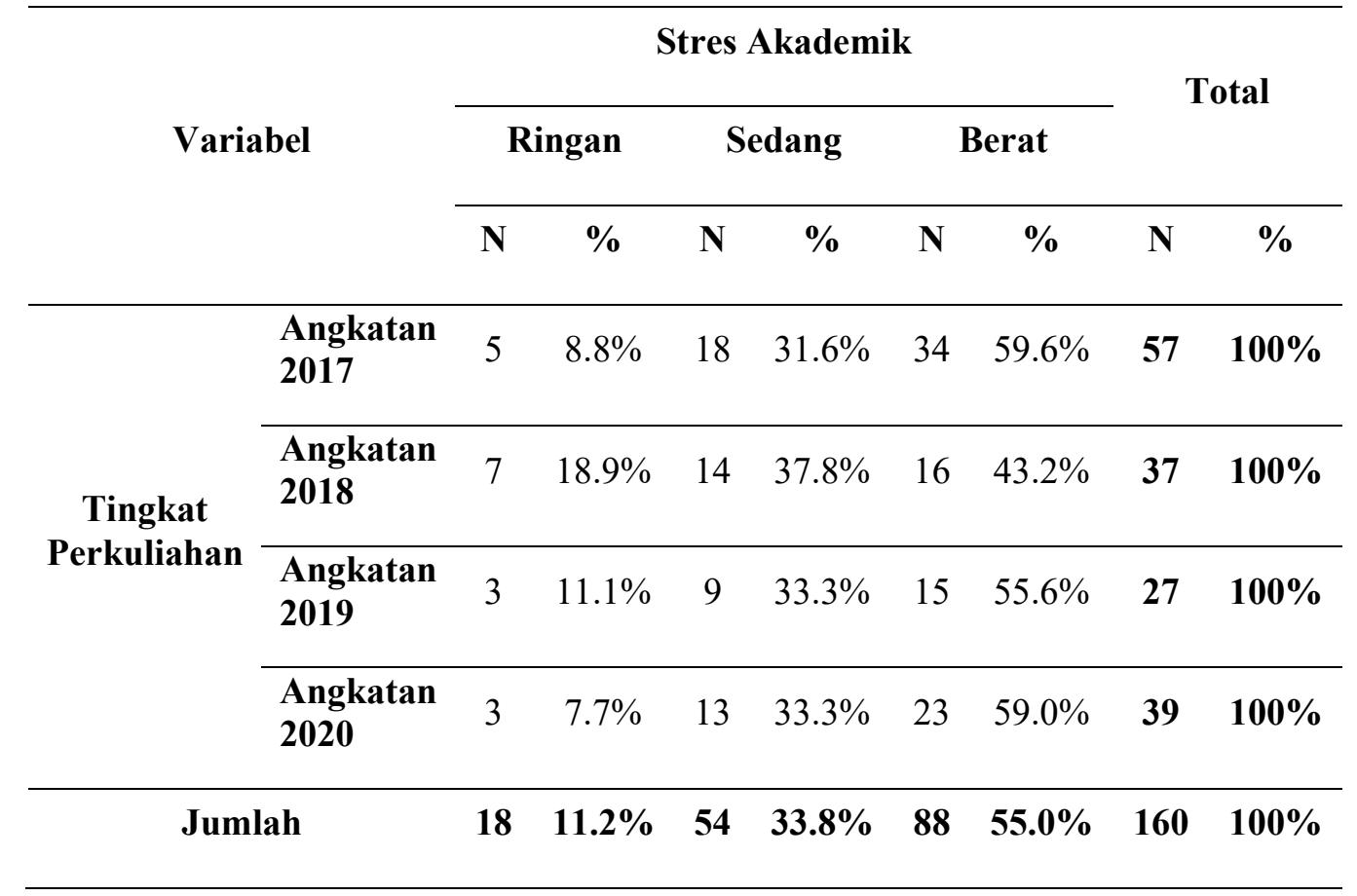


Mahasiswi yang mengalami stres akademik berat sebanyak 88 responden (55\%), sedangkan responden dengan stres akademik ringan sebanyak 18 responden $(11.2 \%)$ dan responden dengan stres akademik sedang sebanyak 54 responden (33.8\%). Penelitian terdahulu melaporkan hasil penelitian bahwa sebanyak 34.3\% mahasiswa mengalami stres akademik sedang, sebagian mengalami stres berat (25.7\%) dan stres ringan sebanyak (14.3\%). Semakin dewasa usia mahasiswa maka tingkat stres akademik yang dialaminya akan semakin rendah. Hal ini dapat terjadi karena ketika seseorang sering terpapar oleh stressor yang sama dan dengan pola yang sama, maka orang tersebut akan terbiasa dan lebih siap dalam mempersepsikan stresor tersebut. Selain itu seiring bertambahnya usia, maka seseorang dapat dengan baik mengontrol tingkat stres akademiknya (Rosaline \& Anggraeni, 2020).

Pada penelitian ini juga didapatkan hasil analisa bahwa mayoritas mahasiswi di setiap tingkat perkuliahan mengalami stres akademik berat. Mahasiswi tingkat 1 banyak yang mengalami kondisi stres akademik berat karena individu belum terbiasa dengan kondisi di dunia perkuliahan. Pernyataan ini didukung oleh hasil wawancara yang dilakukan Merry \& Mamahit, (2020) pada mahasiswa tingkat awal, yang menyatakan beban pembelajaran di perguruan tinggi lebih banyak daripada di SMA (Merry \& Mamahit, 2020). Stres akademik pada mahasiswi tingkat 2 dan tingkat 3 dapat disebabkan karena perubahan metode pembelajaran yang mendadak, tugas pembelajaran, kompetisi antar teman sebaya, kondisi jaringan internet yang tidak stabil dan kondisi lingkungan rumah yang tidak kondusif. Sedangkan, pada mahasiswi tingkat 4 kondisi stres akademik berat ini dapat disebabkan karena tuntutan akademik, terutama tanggung jawab mahasiswi terhadap tugas akhir. Proses menyusun tugas akhir menjadi faktor penyebab stres akademik utama pada mahasiswi tingkat akhir (P. D. Ambarwati, Pinilih, \& Astuti, 2019).

Mahasiswi tidak dapat menghilangkan penyebab stres, tetapi memiliki kemampuan untuk mengontrol diri dan emosinya. Maka dari itu, setiap orang harus memahami strategi koping untuk mengatasi stressor. Strategi yang dapat dilakukan oleh individu yaitu emotional focused coping dimana individu fokus untuk mengatur emosinya dan mencoba untuk beradaptasi dengan perubahan yang terjadi. Cara yang dapat dilakukan individu berupa selalu berpikiran positif terhadap suatu masalah, mencoba menerima masalah atau mengendalikan diri untuk kemudian 
mencari solusi masalah. Selain itu, individu dapat menerapkan strategi koping problem focused coping yaitu suatu metode koping yang dapat dilakukan individu untuk mengatasi dan menyelesaikan masalahnya dengan cara mempelajari hal-hal baru. Pada strategi ini individu dapat mencari strategi terbaik ataupun mencari dukungan sosial dalam menghadapi suatu masalah (Maryam, 2017). Institusi pendidikan

melalui para pendidik dapat memberikan promosi kesehatan mengenai strategi koping stres yang dapat dilakukan oleh mahasiswa/i. Selain itu institusi pendidikan, dapat membuat program konseling untuk membatu para mahasiswinya mengatasi kondisi stres akademik (Saniskoro \& Akmal, 2017).

\section{b. Kualitas Tidur}

Table 3 Distribusi Frekuensi Responden Berdasarkan Kualitas Tidur pada Mahasiswi Program Studi S1 Keperawatan di UPN Veteran Jakarta Tahun 2021 (n=160; Juni - April 2021)

\begin{tabular}{|c|c|c|c|c|c|c|c|}
\hline & & \multicolumn{4}{|c|}{ Kualitas Tidur } & \multicolumn{2}{|c|}{ Total } \\
\hline \multicolumn{2}{|c|}{ Variabel } & \multicolumn{2}{|c|}{ Baik } & \multicolumn{2}{|c|}{ Buruk } & \multirow[b]{2}{*}{$\mathbf{N}$} & \multirow[b]{2}{*}{$\%$} \\
\hline & & $\mathbf{N}$ & $\%$ & $\mathbf{N}$ & $\%$ & & \\
\hline \multirow[t]{4}{*}{$\begin{array}{c}\text { Tingkat } \\
\text { Perkuliahan }\end{array}$} & $\begin{array}{l}\text { Angkatan } \\
2017\end{array}$ & 7 & $12.3 \%$ & 50 & $87.7 \%$ & 57 & $100 \%$ \\
\hline & $\begin{array}{l}\text { Angkatan } \\
2018\end{array}$ & 3 & $8.1 \%$ & 34 & $91.9 \%$ & 37 & $100 \%$ \\
\hline & $\begin{array}{l}\text { Angkatan } \\
2019\end{array}$ & 6 & $22.2 \%$ & 21 & $77.8 \%$ & 27 & $100 \%$ \\
\hline & $\begin{array}{l}\text { Angkatan } \\
2020\end{array}$ & 4 & $10.3 \%$ & 35 & $89.7 \%$ & 39 & $100 \%$ \\
\hline \multicolumn{2}{|c|}{ Jumlah } & 20 & $12.5 \%$ & 140 & $87.5 \%$ & 160 & $100 \%$ \\
\hline
\end{tabular}

Sumber : Data Primer April - Juni 2021

Hasil penelitian menunjukkan distribusi frekuensi responden berdasarkan kualitas tidur pada mahasiswi S1 Keperawatan, UPN Veteran Jakarta. Pada penelitian ini didapatkan sebesar 140 responden $(87.5 \%)$ memiliki kualitas tidur yang buruk dan terdapat 20 responden
(12.5\%) memiliki kualitas tidur yang baik. Berdasarkan pada hasil penelitian ini didapatkan hasil sebagian besar mahasiswi memiliki waktu tidur $<5$ jam per hari. Selain itu, kebanyakan mahasiswi S1 Keperawatan menilai kualitas tidurnya cukup buruk dan mengalami disfungsi 
siang hari dengan kejadian 1-2 kali dalam seminggu. Kualitas tidur yang buruk pada mahasiswi S1 Keperawatan dapat disebabkan oleh tugas kelompok, tugas individu, jadwal perkuliahan yang padat serta deadline pengumpulan tugas yang terlalu cepat. Hal ini, diperkuat dengan hasil penelitian mengenai faktor penyebab stres pada mahasiswi selama proses pembelajaran jarak jauh, yang melaporkan bahwa tugas pembelajaran yang diperoleh mahasiswi selama PJJ lebih banyak daripada pemebelajaran di kampus (Kusnayat et al., 2020). Mahasiswi mengalami penurunan durasi tidur karena memikirkan tugas. Pernyataan tersebut sejalan dengan teori Ratnaningtyas \& Fitriani, (2019) bahwa kualitas tidur buruk pada mahasiswi dapat disebabkan karena mahasiswi memiliki tanggung jawab untuk menyelesaikan tugasnya, sehingga mengakibatkan mahasiswi tidur terlambat dan mengubah pola tidurnya supaya tugas pembelajaan dapat selesai tepat waktu (Ratnaningtyas \& Fitriani, 2019). Selain itu dapat juga dipengaruhi oleh penggunaan media elektronik terutama handphone. Pernyataan tersebut sejalan dengan penelitian yang melaporkan adanya hubungan antara penggunaan gadget dengan kualitas tidur mahasiswa keperawatan (Subhan, 2018). Walaupun mahasiswa lebih banyak menghabiskan waktu di tempat tidur, namun secara keseluruhan kualitas tidur mahasiswa memburuk selama proses pembelajaran jarak jauh di masa pandemi Covid-19 (Romero-Blanco et al., 2020). Di masa pandemi Covid-19 diketahui terjadi penurunan kualitas tidur pada mahasiswa dengan presentasi kualitas tidur yang memburuk selama pandemi sebesar 73,3\% (Marelli et al., 2020).

Kualitas tidur yang buruk dapat menyebabkan berbagai dampak negatif terhadap kesehatan fisik, mental dan kualitas hidup para mahasiswi (Proborini, 2018). Kualitas tidur yang buruk pada mahasiswa dapat diatasi dengan melakukan manajemen waktu yang baik dan melakukan perubahan pola tidur harian. Pola tidur adalah bentuk dari kebiasaan setiap individu untuk mengistirahatkan tubuhnya dengan cara tidur dalam jangka waktu yang menetap. Pola tidur dapat mempengaruhi kualitas tidur individu, karena pola tidur meliputi jadwal tidur dan bangun, frekuensi tidur dan durasi tidur (Widiyanto, 2016). Hal tersebut dibuktikan dengan sebuah penelitian yang melaporkan bahwa mayoritas individu yang memiliki pola tidur yang buruk akan mengalami penurunan kualitas tidur. Hasil uji statistik yang telah dilakukan pada penelitian 
tersebut juga melaporkan adanya pengaruh yang siginifikan antara pola tidur terhadap kualitas tidur mahasiswa (Ahmad, Rijal, \& Haryati, 2020).

Selain itu, kualitas tidur yang buruk pada mahasiswi dapat diatasi dengan menciptakan tempat yang nyaman untuk tidur dan meminimalisir kegiatan yang dapat mengganggu tidur seperti penggunaan gadget. Penggunaan gadget dapat menciptakan rangsangan cahaya, suara dan getaran yang dapat menyebabkan seseorang akan terus terjaga (Keswara, Syuhada, \& Wahyudi, 2019). Kenyamanan tempat tidur dapat memberikan dampak positif terhadap kualitas tidur seseorang. Kondisi suhu ruangan, kebisingan tempat tinggal dan pencahayaan ruang tidur dapat memengerahui kualitas tidur seseorang (Gunarsa \& Wibowo, 2021). Suhu kamar dapat disesuaikan dengan suhu yang diinginkan masing-masing individu, kedinginan atau kegerahan dapat menyebabkan gangguan tidur. Lingkungan rumah yang bising juga dapat menyebabkan gangguan tidur, karena suara dapat merangsang indra pendengaran dan otak sehingga dapat menyebabkan seseorang terbangun dari tidurnya. Pencahayaan ruang tidur, dapat mempengaruhi pengeluaran hormone melatonin yang berperan terhadap fungsi biologis dan membuat individu semakin terlelap. Hormon melatonin dapat diproduksi dengan maksimal pada keadaan gelap. (R. Ambarwati, 2017; Sulistiyani, 2012). Aromaterapi juga dapat digunakan untuk meningkatkan kualitas tidur, karena kandungan pada aromaterapi dapat memberikan efek rileks kepada individu (M. F. E. P. Putri, Murtaqib, \& Hakam, 2018).

\section{Variabel Dependen}

\section{a. Derajat Sindrom Pramenstruasi}

Table 4 Distribusi Frekuensi Responden Berdasarkan Derajat Sindrom Pramenstruasi (PMS) pada Mahasiswi Program Studi S1 Keperawatan di UPN Veteran Jakarta Tahun 2021 (n=160; April - Juni 2021)

Variabel

\section{Frekuensi}

(n)
Presentase

$(\%)$

\section{Sindrom Pramenstruasi :}




\begin{tabular}{ccc}
\hline Keluhan PMS Sedang & 69 & 43.1 \\
\hline Keluhan PMS Berat & 61 & 38.1 \\
\hline Total & $\mathbf{1 6 0}$ & $\mathbf{1 0 0}$ \\
\hline
\end{tabular}

Sumber : Data Primer April - Juni 2021

Tabel 4 menunjukkan bahwa mayoritas mahasiswi S1 Keperawatan, UPN Veteran Jakarta mengalami derajat sindrom pramenstruasi sedang yaitu sebanyak 69 responden (43.1\%). Pada penelitian ini juga ditemukan sebesar 61 responden (38.1\%) mengalami sindrom pramenstruasi berat, 30 responden $(18.8 \%)$ mengalami derajat sindrom pramenstruasi ringan dan tidak ada mahasiswi yang tidak memiliki keluhan PMS. American college of Obstetricians and Gynaecologist menyatakan teori bahwa $85 \%$ wanita usia subur akan merasakan paling sedikit satu dari gejala PMS di setiap siklus menstruasinya (Hutasuhud, 2018). Data yang didapatkan pada penelitian ini adalah seluruh gejala PMS pada kuesioner dirasakan oleh responden namun dengan frekuensi yang berbeda. Pada penelitian ini didapatkan bahwa 5 gejala yang paling sering dirasakan yaitu perasaan sedih \& tidak bersemangat \& sensitive, mudah marah \& mudah tersinggung, merasa tertekan, nyeri perut dan nyeri sendi.

PMS dapat dipengaruhi oleh berbagai faktor seperti faktor hormonal, faktor genetik dan faktor psikologis (Afrilia \& Musa, 2020; Lumingkewas et al., 2021;
Noor \& Norfitri, 2015; Rodiani \& Rusfiana, 2016; Endah Susilowati \& Prasetyo, 2015). Sindrom pramenstruasi dapat berdampak pada tingkat kualitas hidup wanita (Noor \& Norfitri, 2015). Sindrom pramenstruasi yang dialami oleh para mahasiswi dapat menganggu produktifitas pendidikan, menyebabkan ketidakhadiran, meningkatkan biaya perawatan kesehatan, mengganggu aktivitas sehari-hari dan dapat mempengarhi kesehatan mental seperti depresi dan insomnia (Fugate Woods \& Kenney, 2019; Pertiwi, 2016; Shahbazi, 2020). Penting bagi mahasiswi untuk mengetahui faktor risiko dan penanganan PMS lebih lanjut. Institusi pendidikan melalui para pendidiknya atau organisasi mahasiswa dapat memberikan konseling atau pendidikan kesehatan terkait penyebab PMS dan cara penanganannya yang tepat. Hal ini sejalan dengan penelitian yang menyatakan bahwa terdapat pengaruh antara pengetahuan mahasiswi terhadap perilaku mengatasi PMS (Puspitaningrum, 2018). 


\section{Analisa Bivariat}

a. Stres Akademik - Derajat Sindrom

\section{Pramenstruasi}

Table 5 Analisis Hubungan Stres Akademik terhadap Derajat Sindrom Pramenstruasi (PMS) pada Mahasiswi Program Studi S1 Keperawatan di UPN Veteran Jakarta Tahun 2021 (n=160; April - Juni 2021)

\begin{tabular}{|c|c|c|c|c|c|c|c|c|c|c|}
\hline \multirow{2}{*}{\multicolumn{2}{|c|}{ Variabel }} & \multicolumn{6}{|c|}{ Derajat Sindrom Pramenstruasi } & \multirow{2}{*}{\multicolumn{2}{|c|}{ Total }} & \multirow{3}{*}{$\underset{\text { Value }}{p-}$} \\
\hline & & \multicolumn{2}{|c|}{ Ringan } & \multicolumn{2}{|c|}{ Sedang } & \multicolumn{2}{|c|}{ Berat } & & & \\
\hline & & $\mathbf{N}$ & $\%$ & $\mathbf{N}$ & $\%$ & $\mathbf{N}$ & $\%$ & $\mathbf{N}$ & $\%$ & \\
\hline \multirow{3}{*}{$\begin{array}{c}\text { Stres } \\
\text { Akademik }\end{array}$} & Ringan & 15 & $83.3 \%$ & 3 & $16.7 \%$ & 0 & $00.0 \%$ & 18 & $100 \%$ & \multirow{4}{*}{0.000} \\
\hline & Sedang & 10 & $18.5 \%$ & 32 & $59.3 \%$ & 12 & $22.2 \%$ & 54 & $100 \%$ & \\
\hline & Berat & 5 & $5.7 \%$ & 34 & $38.6 \%$ & 49 & $55.7 \%$ & 88 & $100 \%$ & \\
\hline \multicolumn{2}{|c|}{ Jumlah } & 30 & $18.8 \%$ & 69 & $43.1 \%$ & 61 & $38.1 \%$ & 160 & $100 \%$ & \\
\hline
\end{tabular}

Sumber : Data Primer April - Juni 2021

Hasil dari uji statistik Chi Square, didapatkan nilai p-value 0.000 maka dapat ditarik kesimpulan p-value $<0.050$ sehingga $\mathrm{H}_{\mathrm{a}}$ diterima dan $\mathrm{H}_{0}$ ditolak, yang artinya terdapat hubungan yang bermakna antara stres akademik dengan derajat sindrom pramenstruasi. Derajat sindrom pramenstruasi dapat meningkat seiring dengan adanya gangguan psikis atau emosi seorang individu (K. M. Putri, 2017). Berdasarkan penelitian ini sebanyak 49 responden (57\%) mengalami kondisi stres akademik berat dengan derajat sindrom pramenstruasi berat. Hal ini dapat terjadi karena pada saat seseorang dalam keadaan stres, aksis Hypotalamic Pituitary Axis
(HPA) menjadi aktif yang mengakibatkan produksi hormon kortisol. Hormon kortisol yang diproduksi dapat menyebabkan pelepasan Gonadotropin Releasing Hormon $(\mathrm{GnRH})$ dan Leutinizing Hormon (LH) menjadi terhambat. Padahal dalam siklus menstruasi LH memiliki peran yang sangat penting yaitu menghasilkan hormon estrogen dan progesteron. Dengan adanya produksi hormon kortisol ini, dapat menyebabkan terjadinya ketidakseimbangan hormon yang merupakan faktor penyebab utama kejadian sindrom pramenstruasi (Ilmi \& Utari, 2018b). 
Pada penelitian ini juga ditemukan mahasiswi dengan kondisi stres akademik ringan mengalami PMS ringan (83.3\%) dan PMS sedang (16.7\%). Kejadian seperti ini dapat terjadi, karena banyak faktor yang dapat mempengaruhi derajat sindrom pramenstruasi, seperti faktor hormon, faktor genetik, aktivitas fisik, status gizi, (Afrilia \& Musa, 2020; Lumingkewas et al., 2021; Noor \& Norfitri, 2015; Rodiani \& Rusfiana, 2016; Endah Susilowati \& Prasetyo, 2015). Selain itu pada penelitian ini juga didapatkan beberapa kondisi yang dapat mempengaruhi derajat sindrom pramenstruasi seperti kondisi abnormal pada usia menarche, lama menstruasi, siklus menstruasi dan riwayat keluarga dengan PMS.

Penelitian lain melaporkan bahwa gangguan psikologi individu dapat memperberat sindrom pramenstruasi (Puji, Ismaya, Ratnaningtyas, Hasanah, \& Fitriah, 2021). Hal tersebut dibuktikan dengan hasil uji statistik yang menyatakan terdapat hubungan antara stres akdemik dengan kejadian sindrom pramenstruasi pada mahasiswi, dengan nilai p-value 0.001 . Pada penelitian tersebut, dikatakan bahwa terdapat 3 gejala PMS yang paling sering dirasakan responden yaitu gejala sedih dan tidak bersemangat, sensitive dan nyeri pinggul, punggung dan sendi (Puji et al.,
2021). Selain itu, hasil dari penelitian ini juga sejalan dengan hasil penelitian Fidora \& Yuliani, yang melaporkan bahwa terdapat hubungan yang bermakna antara tingkat stres dengan keluhan sindrom pramenstruasi ( $p$-value 0.001) (Fidora \& Yuliani, 2020). Dalam penelitian tersebut, didapatkan korelasi positif yang dapat diinterpretasikan bahwa semakin berat kondisi stres akademik yang dialami, maka semakin parah keluhan sindrom pramenstruasi yang dirasakannya (Fidora \& Yuliani, 2020). Tingkat stres akademik secara statistik memiliki hubungan dengan kejadian sindrom pramenstruasi dengan $p$ value $0.015<0.05$. Kegiatan akademik yang mengandung banyak stressor dapat meningkatkan keparahan sindrom pramenstruasi, karena terdapat fluktuasi hormon esterogen dan progesteron (Afrilia \& Musa, 2020). Penelitian yang dilakukan pada mahasiswi Visvesvaraya Technological University juga melaporkan bahwa kondisi stres pada mahasiswi berhubungan dengan keparahan sindrom pramenstruasi di masa pandemi Covid-19 (Dhawan \& Hernole, 2020). Kondisi stres menyebabkan peningkatan kortisol yang dapat mempengaruhi keseimbangan hormon esterogen dan kemudian meningkatkan derajat sindrom pramenstruasi (Dhawan \& Hernole, 2020). 
Selain itu, terdapat hasil penelitian terdahulu yang menghasilkan hasil penelitian yang bertolak belakang dengan hasil pada penelitian ini dan beberapa penelitian yang sudah dijelaskan diatas. Pada penelitian tersebut, dilaporkan bahwa tidak ada hubungan yang bermakna antara tingkat stres dengan kejadian PMS, dengan p-value 0.231 (Ritung \& Olivia, 2018). Hal tersebut dapat terjadi karena mahasiswi kedokteran mampu mengelola kondisi stres dengan baik, yang dibuktikan dari hasil penelitian tersebut yang menyatakan mayoritas responden (58.4\%) tidak mengalami stres. Selain itu, mahasiswi kedokteran memiliki pengetahuan yang baik tentang stres dan sindrom pramenstruasi (Puspitaningrum, 2018; Ritung \& Olivia, 2018). Psikoedukasi tentang menstruasi dapat meningkatkan pengetahuan dan menurunkan derajat sindrom pramenstruasi (Setiawati, Wijaya, \& Wahyuningsih, 2020). Namun hasil dari penelitian Ritung \& Olivia (2018), tidak sesuai dengan teori yang menyatakan bahwa kondisi stres hebat dari jenis stres apapun dapat menyebabkan gangguan menstruasi (Guyton \& Hall, 2016). Maka hasil penelitian yang didapatkan pada penelitian ini dapat memperkuat teori dari Guyton \& Hall dan hasil penelitian terdahulu yang menyatakan bahwa terdapat hubungan antara stres akademik dengan derajat sindrom pramenstruasi pada mahasiswi (Guyton \& Hall, 2016; Puji et al., 2021).

\section{b. Kualitas Tidur - Derajat Sindrom Pramenstruasi}

Table 1 Analisis Hubungan Kualitas Tidur terhadap Derajat Sindrom Pramenstruasi (PMS) pada Mahasiswi Program Studi S1 Keperawatan di UPN Veteran Jakarta Tahun 2020 (n=160)

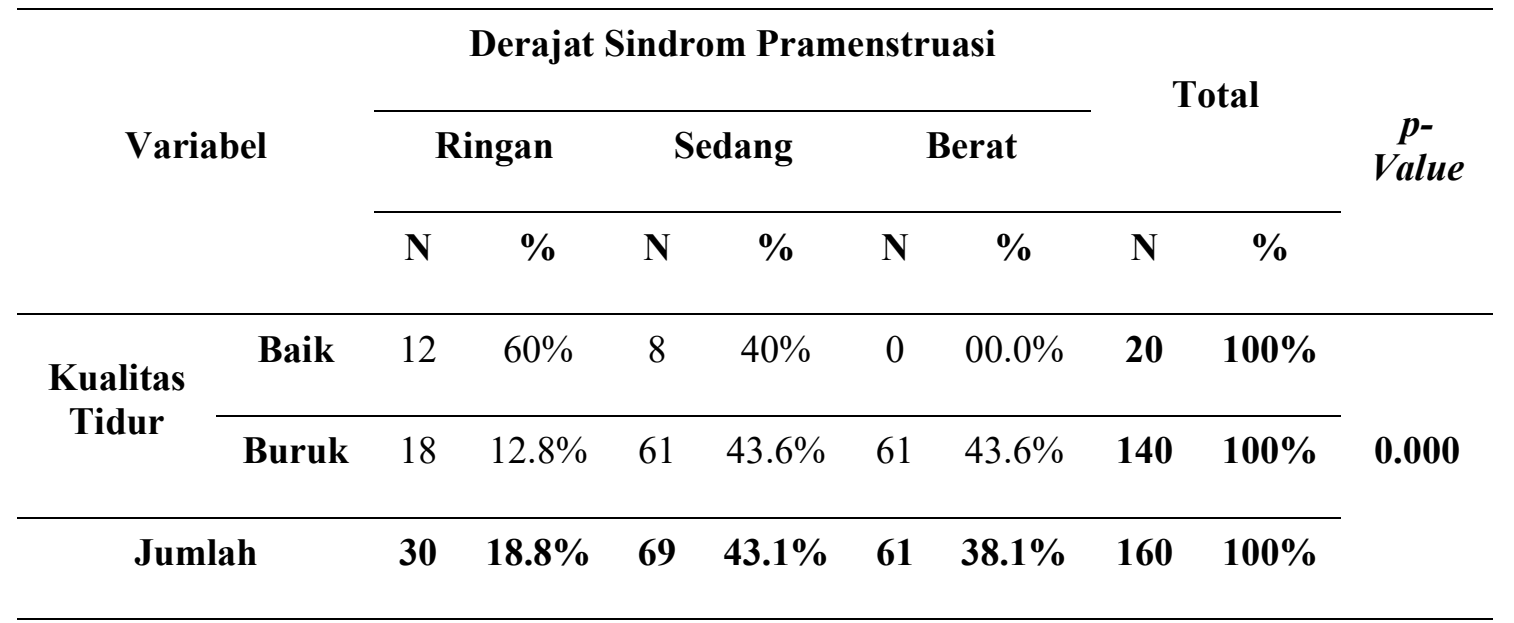


Hasil penelitianmelaporkan bahwa kualitas tidur yang buruk dapat meningkatkan keparahan sindrom pramenstruasi. Hal tersebut dibuktikan dengan hasil uji statistik nilai $p$-value $=0.00$, yang artinya terdapat hubungan antara kualitas tidur dengan keparahan sindrom pramenstruasi. Kualitas tidur yang baik dapat mempercepat pemulihan kondisi tubuh baik secara fisiologis maupun psikologis (Puji et al., 2021). Penelitian lain juga melaporkan adanya hubungan yang signifikan antara kualitas tidur terhadap derajat sindrom pramenstruasi dengan nilai $p$-value 0.029 (Ilmi \& Utari, 2018b). Kualitas tidur yang baik (tidur tanpa gangguan) dapat meringankan derajat PMS, hal ini dikarenakan baik atau buruknya kualitas tidur individu dapat mempengaruhi proses sekresi berbagai hormon pada saat tidur (Ilmi \& Utari, 2018b; Ozisik Karaman, Tanriverdi, \& Degirmenci, 2012). Penelitian yang meneliti tentang penilaian kualitas tidur secara subjektif pada mahasiswi Universitas Visvesvaraya melaporkan adanya pengaruh antara kualitas tidur dengan derajat sindrom pramenstruasi (Dhawan \& Hernole, 2020). Perubahan pada durasi tidur dan gangguan yang terjadi pada saat tidur mempengaruhi pengeluaran beberapa hormon dan menyebabkan peningkatan keluhan sindrom pramenstruasi (Dhawan \& Hernole, 2020).

Berdasarkan hasil pada penelitian ini didapatkan, mahasiswi dengan kualitas tidur yang buruk mengalami sindrom pramenstruasi sedang (43.6\%) dan sindrom pramenstruasi berat (43.6\%). Hal ini dapat terjadi karena kualitas tidur dapat mempengaruhi pengeluaran berbagai hormon yang diproduksi oleh tubuh (Boivin \& Shechter, 2010; Nelson, 2017). Meskipun kualitas tidur yang buruk merupakan salah efek samping dari PMS, namun berdasarkan beberapa penelitian dikatakan bahwa kualitas tidur yang buruk dapat meningkatakan derajat sindrom pramenstruasi yang dirasakan wanita (Dhawan \& Hernole, 2020; Lisnawati, 2017). Individu yang mengalami penurunan kualitas tidur akan menyebabkan produksi hormon melatonin menurun. Kadar hormon melatonin yang menurun, mengakibatkan produksi hormon estrogen meningkat, sehingga terjadi ketidakseimbangan hormon estrogen dan hormon progestreron yang dapat menimbulkan sindrom pramenstruasi (Lovani, 2019). Mahasiswi yang memiliki kualitas tidur buruk akan memiliki peluang yang lebih besar untuk mengalami derajat sindrom pramenstruasi sedang hingga berat. Penyataan tersebut sejalan dengan penelitian yang melapokan bahwa mahasiswi dengan kualitas tidur 
yang buruk berisiko 3.5 kali lebih besar untuk mengalami PMS daripada mahasiswi dengan kualitas tidur yang baik (Ilmi \& Utari, 2018b).

Pada penelitian ini juga ditemukan mahasiswi dengan kualitas tidur baik mengalami PMS ringan (60\%) dan PMS sedang (40\%). Kejadian seperti ini dapat terjadi, karena banyak faktor yang dapat mempengaruhi derajat sindrom pramenstruasi, seperti faktor hormon, faktor genetik (Afrilia \& Musa, 2020; Lumingkewas et al., 2021; Noor \& Norfitri, 2015; Rodiani \& Rusfiana, 2016; Endah Susilowati \& Prasetyo, 2015). Selain itu, pada penelitian ini juga didapatkan beberapa responden yang memiliki kondisi abnormal pada usia menarche, lama menstruasi dan siklus menstruasi yang mana kondisi tersebut berhubungan dengan faktor hormonal dan faktor genetik. Hasil yang didapatkan pada penelitian ini memperkuat hasil penelitian terdahulu yang menyatakan bahwa terdapat hubungan antara kualitas tidur dengan derajat sindrom pramenstruasi pada mahasiswi (Puji et al., 2021).

\section{SIMPULAN}

Peningkatan kasus Covid-19 yang begitu tinggi membuat pemerintah menerapkan berbagai macam kebijakan guna menekan laju penularan Covid-19. Proses pembelajaran jarak jauh sebagai salah satu upaya yang diterapkan pemerintah pada institusi pendidikan. Pembelajaran jarak jauh yang dilakukan di masa pandemi Covid-19 cukup memicu kondisi stres dan kualitas tidur yang memburuk pada mahasiswi. Dua kondisi tersebut dapat menimbulkan keluhan sindrom pramenstruasi. Hasil penelitian menunjukkan bahwa terdapat korelasi yang signifikan antara stres akademik ( $p$-value 0.000) dan kualitas tidur ( $p$-value 0.000) terhadap derajat sindrom pramenstruasi.

Pada penelitian ini didapatkan bahwa ada korelasi yang significant antara stres akademik dan kualitas tidur terhadap derajat sindrom pramenstruasi. Hasil dari penelitian ini dapat menjadi tambahan teori dan refrensi bahwa stres akademik dan kualitas tidur merupakan dua kondisi yang dapat mempengaruhi derajat sindrom pramenstruasi. Bagi mahasiswi diharapkan dapat mengontrol diri dan emosinya untuk meminimalisir kondisi stres akademik dengan mengaplikasikan berbagai macam strategi koping emotional focused coping dan problem focused coping. Kualitas tidur yang buruk pada mahasiswa dapat diatasi dengan melakukan manajemen waktu yang baik dan melakukan perubahan pola tidur harian. Ketika kondisi stres akademik dan kualitas tidur buruk dapat dikontrol dan dikelola dengan baik diharapkan dapat 
menekan kejadian sindrom pramenstruasi. Bagi peneliti berikutnya, penelitian ini dapat dijadikan acuan ataupun refrensi dalam melakukan penelitian selanjutnya yang berhubungan dengan faktor risiko sindrom pramenstruasi.

\section{UCAPAN TERIMA KASIH}

Penelitian ini dapat berjalan dengan baik berkat keterlibatan dari berbagai pihak. Oleh sebab itu, peneliti mengucapkan terima kasih kepada dosen pembimbing, Dekan Fakultas Ilmu Kesehatan UPN Veteran Jakarta, Ketua Program Studi S1 Keperawatan UPN Veteran Jakarta dan Mahasiswi S1 Keperawatan UPN Veteran Jakarta yang telah membantu peneliti dalam melancarkan penelitian ini.

\section{DAFTAR RUJUKAN}

Afrilia, E. M., \& Musa, S. M. (2020). Analisis Pramenstruasi Sindrom pada Siswi SMAN 3 Kota Tangerang Tahun 2019. UMT Journal Systems Portal (UMTJSP), 2, 262-269.

Ahmad, I. E., Rijal, S., \& Haryati, H. (2020). Faktor yang Mempengaruhi Kualitas Tidur Mahasiswa Fakultas Kedokteran Universitas Halu Oleo. Jurnal Surya Medika, 5(2), 42-53. https://doi.org/10.33084/jsm.v5i2.129 0

Ambarwati, P. D., Pinilih, S. S., \& Astuti, R. T. (2019). Gambaran Tingkat Stres Mahasiswa. Jurnal Keperawatan Jiwa, 5(1), 40. https://doi.org/10.26714/jkj.5.1.2017.4
$0-47$

Ambarwati, R. (2017). Tidur, Irama Sirkadian dan Metabolisme Tubuh. Jurnal Keperawatan, X(1), 42-46. Retrieved from http://www.litbang.kemkes.go.id:8080 /handle/123456789/33428

Andriana, Aldriana, N., \& Andria. (2018). Factors Influencing Menstrual Cycle at Female Students of University of Pasir Pengaraian. Jurnal Maternity and Neonatal, 2(5), 271-. Retrieved from http://ejournal.upp.ac.id/index.php/akbd/articl e/view/1596

Christie, K. D., Citraningtyas, T., Ingkiriwang, E., \& Soesanto, A. A. (2019). Faktor Risiko Sindrom Premenstruasi pada Sampel Urban di Jakarta Februari-Maret 2018. Jurnal Kedokteran Meditek, 24(68), 1-7. https://doi.org/10.36452/jkdoktmedite k.v24i68.1695

Dhawan, A., \& Hernole, J. (2020). Effect of Perceived Pandemic Stress and Sleep Variation on Menstrual Cycle Occurrence, its Severity and Premenstrual Syndrome: A Cross Sectional Study. Journal of Women's Health and Development, 03(04), 437-445. https://doi.org/10.26502/fjwhd.264428840052

Dhull, I., \& Kumari, S. (2015). Academic stress among adolescents in relation to gender. International Journal of Applied Research, 1, 394-396.

Direkvand-Moghadam, A., Sayehmiri, K., Delpisheh, A., \& Satar, K. (2014). Epidemiology of premenstrual syndrome, a systematic review and 
meta-analysis study. Journal of Clinical and Diagnostic Research, 8(2), 106-109. https://doi.org/10.7860/JCDR/2014/80 24.4021

Fatimah, A., Prabandari, Y. S., \& Emilia, O. (2016). Stres dan kejadian premenstrual syndrome pada mahasiswi pondok pesantren Surya Global. Berita Kedokteran Masyarakat, 32(1), 13. https://doi.org/10.22146/bkm.8452

Fidora, I., \& Yuliani, N. I. (2020). Hubungan Antara Tingkat Stres Dengan Sindrom Pramenstruasi Pada Siswi Sma. Journal Menara Ilmu, XIV(01), 70-74.

Freeman, E. W. (2007). Epidemiology and Etiology of Premenstrual Syndromes. Retrieved June 20, 2021, from Medscape Ob/Gyn website: https://www.medscape.org/viewarticle 1553603

Fugate Woods, N., \& Kenney, N. J. (2019). Menstrual-Cycle-Related Disorders. In Routledge International Handbook of Women's Sexual and Reproductive Health (Vol. 7). https://doi.org/10.4324/978135103562 $0-8$

Gunarsa, S. D., \& Wibowo, S. (2021). Hubungan Kualitas Tidur Dengan Kebugaran Jasmani Siswa. Jurnal Pendidikan Jasmani, 09(01), 43-52.

Guyton, A. C., \& Hall, J. E. (2016). Textbook Of Medical Physiology (13th ed.). United States: Elsevier.

Hafifah, N., Widiani, E., \& Rahayu, W. H. (2017). Perbedaan Stres Akademik Pada Mahasiswa Program Studi Ilmu Keperawatan Berdasarkan Jenis
Kelamin Di Fakultas Kesehatan Universitas Tribhuwana Tunggadewi Malang. Journal Nursing News, 2(3), 220-229.

Hasanah, U., Ludiana, Immawati, \& PH, L. (2020). Gambaran psikologis mahasiswa dalam proses pembelajaran selama pandemi Covid-19. Jurnal Keperawatan Jiwa, 8(3), 299-306. Retrieved from https://jurnal.unimus.ac.id/index.php/J $\mathrm{KJ} /$ article/view/5941

Hutasuhud, R. M. (2018). Faktor-Faktor Yang Berhubungan Dengan Pre Menstrual Syndrome Pada Remaja Puteri Kelas X Dan Xi Di Pesantren Modren Nurul Hakin Deli Serdang. Excellent Midwifery Journal, Volume 1(No.2), 115-123.

Ilmi, A. F., \& Utari, D. M. (2018a). Faktor Dominan Premenstrual Syndrome Pada Mahasiswi (Studi Pada Mahasiswi Fakultas Kesehatan Masyarakat Dan Departemen Arsitektur Fakultas Teknik, Universitas Indonesia). Journal Media Gizi Mikro Indonesia, 10(1), 39-50. https://doi.org/10.22435/mgmi.v10i1.1 062

Ilmi, A. F., \& Utari, D. M. (2018b). Faktor Dominan Premenstrual Syndrome Pada Mahasiswi (Studi Pada Mahasiswi Fakultas Kesehatan Masyarakat Dan Departemen Arsitektur Fakultas Teknik, Universitas Indonesia). Jurnal Media Gizi Mikro Indonesia, 10(1), 39-50. https://doi.org/10.22435/mgmi.v10i1.1 062

Islamy, A., \& Farida, F. (2019). FaktorFaktor Yang Mempengaruhi Siklus Menstruasi Pada Remaja Putri Tingkat 
Iii. Jurnal Keperawatan Jiwa, 7(1), 13. https://doi.org/10.26714/jkj.7.1.2019.1 3-18

Jannah, R., \& Santoso, H. (2021). Tingkat Stres Mahasiswa Mengikuti Pembelajaran Daring pada Masa Pandemi Covid-19. Jurnal Riset Dan Pengabdian Masyarakat, 1(1), 130146.

Jarvis, C. I., \& Hargreaves, A. (2015). Premenstrual syndrome (PMS) and premenstrual dysphoric disorder (PMDD). The 5-Minute Clinical Consult Standard 2016: Twenty Fourth Edition, (April). https://doi.org/10.1210/jcem.95.4.999 8

Jayakumari, S., Prabhu, K., Johnson, W. M. S., \& Kalaiselvi, V. S. (2016). Menstrual cycle pattern in adolescents girls, in relation to BMI, food habits and the same in their parents. International Journal of Pharmaceutical Sciences Review and Research, 37(2), 37-39.

Joshi, T., Patil, A., Kural, M., Noor, N., \& Pandit, D. (2015). Menstrual characteristics and prevalence of dysmenorrhea in college going girls. Journal of Family Medicine and Primary Care, 4(3), 426. https://doi.org/10.4103/22494863.161345

Karajibani, M., Montazerifar, F., Nazare, N., \& Dashipour, A. R. (2019). The Relationship Between Age at Menarche and Premenstrual Syndrome with Anthropometric Indices in High School Female Students in Zahedan in 2017. Zahedan Journal of Research in Medical Sciences, 22(1). https://doi.org/10.5812/zjrms.93862

Keswara, U. R., Syuhada, N., \& Wahyudi, W. T. (2019). Perilaku penggunaan gadget dengan kualitas tidur pada remaja. Holistik Jurnal Kesehatan, 13(3), 233-239. https://doi.org/10.33024/hjk.v13i3.159 9

Kushartanti, R. (2018). Beberapa Faktor Yang Mempengaruhi Kejadian PreMenstrual Syndrome (Pms) Pada Remaja Putri Di Smak Terang Bangsa Semarang Tahun 2016. Avicenna : Journal of Health Research, 1(2), 112.

https://doi.org/10.36419/avicenna.v1i2 .228

Kusnayat, A., Sumarni, N., Mansyur, A. S., \& Zaqiah, Q. Y. (2020). Pengaruh Teknologi Pembelajaran Kuliah Online Di Era Covid-19 Dan Dampaknya Terhadap Mental Mahasiswa. EduTeach : Jurnal Edukasi Dan Teknologi Pembelajaran, I(2), 153-165.

Lovani, C. (2019). Hubungan Kualitas Tidur dan Tingkat Stres Terhadap Gangguan Menstruasi pada Mahasiswi Program Studi Kedokteran Fakultas Kedokteran Universitas Andalas Angkatan 2015. Universitas Andalas.

Lumingkewas, C., Suparman, E., \& Mongan, S. P. (2021). Gambaran Premenstrual Syndrome pada Remaja Periode Akhir di Fakultas Kedokteran Universitas Sam Ratulangi. Jurnal Universitas Sam Ratulangi, 9(28), 4550. 
https://doi.org/https://doi.org/10.35790 /ecl.9.1.2021.31855

Machfudhoh, Y., Sari, S. Y. I., \& Novina, N. (2020). Premenstrual Syndrome in Children with Type 1 Diabetes Mellitus. Pediatric Oncall Journal, 17(2), 35-39.

https://doi.org/10.7199/ped.oncall.202 0.26

Marelli, S., Castelnuovo, A., Somma, A., Castronovo, V., Mombelli, S., Bottoni, D., ... Ferini-Strambi, L. (2020). Impact of COVID-19 lockdown on sleep quality in university students and administration staff. Journal of Neurology, 268(1), 8-15. https://doi.org/10.1007/s00415-02010056-6

Mariana. (2018). Faktor-Faktor Yang Mempengaruhi Gangguan Premenstrual Syndrome Pada Mahasiswi Akper Yarsi Samarinda. Jurnal Kesehatan Holistik, 12(2), 7482.

Maryam, S. (2017). Strategi Coping: Teori Dan Sumberdayanya. JURKAM: Jurnal Konseling Andi Matappa, 1(2), 101. https://doi.org/10.31100/jurkam.v1i2.1 2

Mau, R. A., Kurniawan, H., \& Dewajanti, A. M. (2020). Artikel Penelitian The Relationship between Menstrual Cycle Interval and Menstrual Duration. Jurnal Kedokteran Meditek, 26(3), 139-145.

https://doi.org/https://doi.org/10.36452 /jkdoktmeditek.v26i3.1946

Merry, \& Mamahit, H. C. (2020). Stres akademik mahasiswa aktif angkatan 2018 dan 2019 Universitas Swasta di DKI Jakarta. Jurnal Konseling
Indonesia, 6(1), 6-13.

Mufida, E. (2017). Faktor yang Meningkatkan Risiko Premenstrual Syndrome pada Mahasiswi. Jurnal Biometrika Dan Kependudukan, 4(1), 7-13.

Nelson, C. L. (2017). The Relationship between Sleep and Sedentary Time, and the Impact of Varying Sleep Patterns. ProQuest Dissertations and Theses, 104. Retrieved from https://manchester.idm.oclc.org/login? url=https://search.proquest.com/docvie $\mathrm{w} / 2015202874$ ? accountid $=12253 \% 0 \mathrm{~A}$ http://man-

fe.hosted.exlibrisgroup.com/openurl/4 4MAN/44MAN_services_page?genre $=$ dissertations $+\% 26+$ theses \&atitle $=\& a$ uthor $=$ Nelson $\% 2 \mathrm{C}+$ Claudia + L.\&volu $\mathrm{me}=\&$

Noor, S., \& Norfitri, R. (2015a). The Changes of Premenstrual Symptoms after Aerobic Exercise Intervention. Jurnal Ners, 10(1), 38-47.

Noor, S., \& Norfitri, R. (2015b). The Changes of Premenstrual Symptoms After Aerobic Exercise Intervention. Jurnal Ners, 10(1), 38-47. https://doi.org/10.20473/jn.V10I12015 $.38-47$

Novia, I., \& Puspitasari, N. (2018). Faktor Risiko yang Mempengaruhi Kejadian Dismenore Primer. The Indonesian Journal of Public Health, 4(2), 96104.

Ozisik Karaman, H. I., Tanriverdi, G., \& Degirmenci, Y. (2012). Subjective sleep quality in premenstrual syndrome. Gynecological Endocrinology, 28(8), 661-664. https://doi.org/10.3109/09513590.201 1.650769 
Pertiwi, C. (2016). Hubungan Aktivitas Olahraga Terhadap Kejadian Sindrom Pramenstruasi Pada Remaja Di SMAN 4 Jakarta. Universitas Islam Negeri Jakarta.

Proborini, H. G. (2018). HUBUNGAN ANTARA KUALITAS TIDUR DENGAN TINGKAT STRES PADA MAHASISWA TINGKAT PERTAMA FAKULTAS KEDOKTERAN UNIVERSITAS PEMBANGUNAN NASIONAL “VETERAN" JAKARTA PERIODE MARET 2018 (Universitas Pembangunan Nasional Veteran Jakarta). Universitas Pembangunan Nasional Veteran Jakarta. Retrieved from

http://repository.upnvj.ac.id/4797/

Puji, L. K. R., Ismaya, N. A., Ratnaningtyas, T. O., Hasanah, N., \& Fitriah, N. (2021). Hubungan Antara Aktivitas Fisik, Stres dan Pola Tidur Dengan Premenstrual Syndrome (PMS) Pada Mahasiswi Prodi D3 Farmasi Stikes Kharisma Persada. Edu Dharma Journal: Jurnal Penelitian Dan Pengabdian Masyarakat, 5(1), 18.

Purwani Sari, E. (2019). FAKTORFAKTOR YANG BERHUBUNGAN DENGAN PERUBAHAN SIKLUS MENSTRUASI PADA MAHASISWI DHARMA HUSADA PEKANBARU TAHUN 2019. Jurnal Martenity and Neonatal, 2(7), 417-429. Retrieved from http://ejournal.upp.ac.id/index.php/akbd/articl e/view/1906

Puspitaningrum, E. M. (2018). Hubungan Pengetahuan Remaja Putri Dengan Perilaku Mengatasi Gejala Premenstrual Syndrome (PMS) Di Man Model Kota Jambi. Jurnal Menara Ilmu, XII(80), 27-32.
Putri, K. M. (2017). Hubungan Aktifitas Fisik Dan Depresi Dengan Kejadian Sindrom Pra Menstruasi. JI-KES (Jurnal Ilmu Kesehatan), 1(1), 18-24. https://doi.org/10.33006/ji-kes.v1i1.55

Putri, M. F. E. P., Murtaqib, M., \& Hakam, M. (2018). Pengaruh Relaksasi Aromaterapi Jasmine terhadap Kualitas Tidur pada Lansia di Karang Werdha. Pustaka Kesehatan, 6(3), 461. https://doi.org/10.19184/pk.v6i3.1174 5

Ratnaningtyas, T. O., \& Fitriani, D. (2019). Hubungan Stres Dengan Kualitas Tidur Pada Mahasiswa Tingkat Akhir. Edu Masda Journal, 3(2), 181. https://doi.org/10.52118/edumasda.v3i 2.40

Ritung, D. C. N., \& Olivia, S. (2018). Hubungan stres terhadap Premenstrual Syndrome (PMS) pada mahasiswi Fakultas Kedokteran Universitas Tarumanagara Angkatan 2011. Tarumanagara Medical Journal, 1(1), 59-62.

Rodiani, \& Rusfiana, A. (2016). Hubungan Premenstrual Syndrome ( PMS ) terhadap Faktor Psikologis pada Remaja The Relationship of Premenstrual Syndrome (PMS) with Psychological Factor in Adolescent. Jurnal Majority, 5(1), 18-22. Retrieved from http://journal.unair.ac.id/downloadfullpapers-aunf37edc8630full.pdf

Romero-Blanco, C., Rodríguez-Almagro, J., Onieva-Zafra, M. D., ParraFernández, M. L., Prado-Laguna, M. D. C., \& Hernández-Martínez, A. (2020). Sleep pattern changes in nursing students during the COVID-19 
lockdown. International Journal of Environmental Research and Public Health, 17(14), 1-11. https://doi.org/10.3390/ijerph1714522 2

Rosaline, M. D., \& Anggraeni, D. T. (2020). Factors Related to Academic Stress During the Covid-19 Pandemic in Nursing Students of UPN Veteran Jakarta. Advances in Health Sciences Research, 30(44), 374-379. https://doi.org/10.2991/ahsr.k.201125. 064

Rosyidah, I., Efendi, A. R., Arfah, M. A., Jasman, P. A., \& Pratami, N. (2020). Gambaran Tingkat Stres Akademik Mahasiswa Program Studi Ilmu Keperawatan Fakultas Keperawatan Unhas. Jurnal Abdi, 2(1), 33-39. Retrieved from https://journal.unhas.ac.id/index.php/k piunhas/article/view/9083

Royal College of Obstetricians and Gynaecologists. (2017). Management of Premenstrual Syndrome. BJOG: An International Journal of Obstetrics and Gynaecology, 124(3), e 73-e105. https://doi.org/10.1111/14710528.14260

Saniskoro, B. S. R., \& Akmal, S. Z. (2017). Peranan Penyesuaian Diri Di Perguruan Tinggi Terhadap Stres Akademik Pada Mahasiswa Perantau Di Jakarta. Jurnal Psikologi Ulayat, 4(1), 96.

https://doi.org/10.24854/jpu12017-82

Setiawati, E., Wijaya, A. A., \& Wahyuningsih, S. (2020). Psikoeduakasi C4ME Untuk Mengatasi Gangguan Sindrom Pramenstruasi Pada Taruni Militer. Jurnal Psikologi Teori Dan Terapan, 11(1), 32. https://doi.org/10.26740/jptt.v11n1.p3 $2-46$

Shahbazi, F. (2020). Prevalence of symptoms and medication use among female medical students and pharmacy clients with premenstrual syndrome: a cross-sectional study in Iran. https://doi.org/10.1002/jppr.1609

Simbolon, P., Sukohar, A., \& Ariwibowo, C. (2018). Hubungan Indeks Massa Tubuh Dengan Lama Siklus Menstruasi Pada Mahasiswi Angkatan 2016 Fakultas Kedokteran Universitas Lampung. Majority, 7(6), 164-170.

Subhan, F. A. (2018). Hubungan Perilaku Penggunaan Gawai dengan Kualitas Tidur Pada Mahasiswa Keperawatan Semester VI (Enam) di Universitas 'Aisyiyah Yogyakarta. Jurnal Unisa, 11. Retrieved from http://digilib2.unisayogya.ac.id/handle /123456789/1015

Sulana, I. O. P., Sekeon, S. A. S., \& Mantjoro, E. M. (2020). Hubungan Tingkat Stres Dengan Kualitas Tidur Mahasiswa Tingkat Akhir Fakultas Kesehatan Masyarakat Universitas Sam Ratulangi. Jurnal Kesmas, 9(7), 37-45. Retrieved from https://ejournal.unsrat.ac.id/index.php/ kesmas/article/view/31609

Sulistiyani, C. (2012). Beberapa Faktor Yang Berhubungan Dengan Kualitas Tidur Pada Mahasiswa. Kesehatan Masyarakat, 1(2), 280-292. Retrieved from https://media.neliti.com/media/publica tions/18762-ID-beberapa-faktor-yangberhubungan-dengan-kualitas-tidurpada-mahasiswa-fakultas-k.pdf

Susilowati, E., \& Prasetyo, E. (2015). Faktor-Faktor yang Berhubungan 
dengan Siklus Menstruasi Peserta KB Aktif Di Desa Jati Kulon Kecamatan Jati Kabupaten Kudus. In Jurnal Ilmiah Kesehatan Keperawatan (Vol. 6). Retrieved from http://ejr.stikesmuhkudus.ac.id/index.p $\mathrm{hp} / \mathrm{jikk} / \mathrm{article} / \mathrm{view} / 152$

Widiyanto, A. H. S. (2016). Perbedaan Pola Tidur Antara Kelompok Terlatih Dan Tidak Terlatih. Medikora, 15(1), 8595.

https://doi.org/10.21831/medikora.v15 i1.10073 